\title{
Identyfikacja i wykorzystanie zasobów lokalnych w budowaniu przewagi konkurencyjnej - przykład regionu lubelskiego
}

\section{Identification and use of local resources in building a competitive advantage; on the example of the Lublin region}

\author{
Jerzy BAŃSKI \\ Instytut Geografii i Przestrzennego Zagospodarowania PAN \\ ul. Twarda 51/55, 00-818 Warszawa \\ jbanski@twarda.pan.pl
}

\begin{abstract}
Zarys treści: Zasoby lokalne to elementy potencjału wewnętrznego określonego obszaru stwarzające możliwości generowania nowych impulsów rozwojowych i kształtowania nowych produktów lokalnych. Wśród zasobów można wyróżnić: wytwarzane produkty materialne, usługi, umiejętności lub wiedzę, lokalne zachowania i zwyczaje, surowce i bogactwa naturalne oraz wydarzenia i miejsca historyczne. Celem tego opracowania jest identyfikacja zasobów lokalnych w woj. lubelskim i przedstawienie przykładów ich wykorzystania do budowy nowych produktów regionalnych, które mogą kształtować przewagę konkurencyjną Lubelszczyzny. W opracowaniu wykorzystano rezultaty badania Diagnoza zasobów lokalnych Lubelszczyzny.
\end{abstract}

Słowa kluczowe: zasoby lokalne, Lubelszczyzna, rozwój lokalny, region

\section{Wprowadzenie}

Sprzeciwem wobec globalizacji i wynikających z niej procesów powielania, dezintegracji i unifikacji jest lokalizm, który przejawia się wzrostem znaczenia ruchów społecznych apologizujących solidarność, humanizm i walory lokalności, zgodnie z zasadą „myśl globalnie, działaj lokalnie". Podejmowane są również próby znalezienia złotego środka, które mają na celu zachowanie cech lokalności przy jednoczesnym wykorzystaniu pozytywnych aspektów globalizacji. Ukuto nawet pojęcie glokalizacja, które wg T. Friedmana (2001) ma być filtrem pozwalającym ratować lokalne dziedzictwo kultury przed ujednolicającym wpływem globalnego kapitalizmu. Chodzi zatem o to, aby społeczeństwo wykorzystywało wszelkie dobrodziejstwa wynikające z globalizacji, a przy tym miało gwarancję zachowania lokalnych lub regionalnych wzorów, tradycji i wartości.

Paradoksalnie procesy globalne przyczyniły się do wzrostu zainteresowania mikroekonomicznym charakterem globalizacji. We współczesnej polityce regionalnej zwraca się dużo uwagi na sposoby skutecznego wykorzystania zasobów wewnętrznych, które stanowią o przewadze konkurencyjnej jednostki terytorialnej. Czynnikiem rozwoju re- 
gionalnego jest aktywizacja potencjału wewnętrznego regionu determinowanego przez posiadane zasoby (Romer 1990). Wysoki poziom potencjału własnego wpływa dodatnio na tworzenie korzystnych warunków życia mieszkańców, a endogeniczna aktywność może spowodować „samopodtrzymywalny” rozwój społeczny i gospodarczy. Podobne założenia przyświecają teoretycznej perspektywie określanej jako kapitał terytorialny (Camagni 2008), zdolności endogenne (Scott i Storper 2003) lub lokalne uwarunkowania i lokalne usieciowienie (Fujita i in. 1999).

We współczesnym okresie programowania (2014-2020) wymiar terytorialny jest jedną z głównych jego zasad. Zakłada się bowiem odejście od postrzegania terytorium poprzez pryzmat granic administracyjnych, przykładając większą uwagę do wewnętrznych potencjałów, istotnych zasobów i barier rozwojowych. W krajach Unii Europejskiej kształtuje się zatem nowy paradygmat polityki rozwoju przestrzennego, uwzględniający w większym niż dotychczas stopniu lokalną specyfikę (Komunikat... 2010). Istotnego znaczenia w budowaniu nowych produktów lokalnych i regionalnych, które stanowią nowy element w kształtowaniu przewagi konkurencyjnej, nabiera endogeniczny potencjał. W działaniach praktycznych chodzi więc przede wszystkim o mądry wybór cech specyficznych, stwarzających najlepsze możliwości dla rozwoju określonych obszarów i koncentrowanie działań w ich obrębie. Wzrasta przy tym zainteresowanie rozwojem małych jednostek terytorialnych, o jednorodnym charakterze, podobnych uwarunkowaniach środowiskowych, społecznych i ekonomicznych.

Zainteresowanie rozwojem małych jednostek terytorialnych ma długoletnią tradycję i sięga lat siedemdziesiątych ubiegłego wieku, kiedy to w krajach Europy Zachodniej zaznaczył się kryzys polityki regionalnej (Parysek 1997). W Polsce zagadnienie rozwoju lokalnego stało się przedmiotem badań w latach osiemdziesiątych ubiegłego wieku (Dutkiewicz i Gorzelak 1988; Hryniewicz 1990; Jałowiecki 1989), ale dopiero dynamiczne procesy globalizacyjne wynikające z kurczenia się przestrzeni społecznej i wykorzystania technologii informacyjnych przyczyniły się do upowszechnienia tej problematyki.

Rozwój lokalny jest efektem gospodarki lokalnej definiowanej jako złożony proces, w którym władze lokalne przy wykorzystaniu zasobów własnych oraz zaangażowaniu partnerów zewnętrznych stymulują rozwój gospodarczy określonej jednostki terytorialnej (Blakely 1989). Samo pojęcie „rozwój lokalny” w zależności od punktu wyjścia (proces, geneza, kategoria działalności, sposób wykorzystania zasobów wewnętrznych, efekty rozwoju itp.) jest różnie definiowane. J. Parysek (1997) utożsamia go z kształtowaniem możliwie najkorzystniejszych warunków życia w lokalnym środowisku, które bazuje na wewnętrznych czynnikach rozwoju, stanowiąc uzupełnienie rozwoju regionalnego. Natomiast R. Brol (1998) uważa, że jest to zharmonizowane i systematyczne działanie społeczności i władzy lokalnej oraz innych podmiotów działających w określonej jednostce terytorialnej (gminie) zmierzające do kreowania nowych i poprawy istniejących warunków użytkowych jednostki i tworzenia korzystnych warunków gospodarczych oraz zapewnienia ładu przestrzennego i ekologicznego.

W literaturze przedmiotu wymienia się szeroki zestaw czynników rozwoju lokalnego, które można najogólniej podzielić na cztery kategorie: 1) społeczno-kulturowe, 2) ekonomiczne, 3) techniczno-organizacyjne i 4) przyrodnicze (Brandenburg 2011; Pretty 1999; Heffner 2007; Trojanek 1994). Przedmiotem tego opracowania są zasoby lokalne będące elementem składowym wszystkich czterech kategorii. Tworzą one zbiór specyficznych cech jednostki terytorialnej wynikających z jej położenia geograficznego, przeszłości hi- 
storycznej, tradycji i szeroko rozumianej aktywności mieszkańców. Są to cechy rzadkie i trudne do kopiowania.

Właściwe uruchomienie i wykorzystanie zasobów specyficznych jest jednym z najważniejszych uwarunkowań we współczesnym rozwoju lokalnym i regionalnym; zasoby takie można nawet nazwać zasobami strategicznymi. Nawiązuje to bezpośrednio do paradygmatu inteligentnej specjalizacji regionalnej, to jest mądrego wyboru priorytetowego sektora, który stwarza najlepsze możliwości dla rozwoju regionu i koncentrowanie działań w jego obrębie. Taki schemat działań ma zwiększyć efektywność wydatkowania publicznych środków. Stymulacja rozwoju z zewnątrz jest ważna, czasami wręcz niezbędna, jednak bez odpowiedniej bazy lokalnej nawet wielkie środki pomocowe mogą zostać zmarnowane (Sobala-Gwosdz 2005). Podobne wnioski wykazały analizy przeprowadzone w ramach programu badawczego Warunki życia społeczeństwa polskiego: problemy i strategie. Stwierdzono w nim, iż oddziaływanie czynników zewnętrznych na rozwój lokalny w głównej mierze zależy od aktywności samego układu lokalnego oraz w przypadku zaistnienia korzystnego finansowo-inwestycyjnego impulsu zewnętrznego, racjonalne wykorzystanie i efekty rozwojowe zależą od kapitału endogennego (Gorzelak 2008).

Literatura podejmująca teoretyczne rozważania na temat zasobów lokalnych i ich roli w rozwoju terytorialnym jest bogata, niewiele jest natomiast opracowań dotyczących konkretnych zasobów oraz ich znaczenia i poziomu wykorzystania. Najczęściej badania odnoszą się do lokalnych społeczności i oceny kapitału ludzkiego i społecznego (Knieć 2010; Starosta 2012; Wasielewski 2009) lub lokalnych produktów rozumianych zazwyczaj jako specyficzne wyroby sektora żywnościowego (Jastrzębski 2010). Celem tego opracowania jest identyfikacja zasobów lokalnych w województwie lubelskim i przedstawienie przykładów ich wykorzystania do budowy nowych produktów regionalnych, które mogą kształtować przewagę konkurencyjną Lubelszczyzny. W opracowaniu wykorzystano rezultaty badania Diagnoza zasobów lokalnych Lubelszczyzny ${ }^{1}$, wykonanego na zlecenie Urzędu Marszałkowskiego Województwa Lubelskiego. Region ten jest dobrym „poligonem" badawczym, bo charakteryzuje go bardzo duże zróżnicowanie warunków przyrodniczych, różnorodność kulturowa, położenie przygraniczne i występowanie obszarów peryferyjnych.

\section{Idea zasobów lokalnych i logika postepowania badawczego}

W rozwoju regionalnym wyróżnia się dwie kategorie zasobów: uniwersalne - powtarzalne i dające się odtworzyć na innym terytorium oraz lokalne (specyficzne) - stanowiące o niepowtarzalności i unikatowości jednostki terytorialnej. Zasoby specyficzne tworzą przewagi konkurencyjne obszaru, na którym występują, bo charakteryzują się zazwyczaj rzadkością występowania. Są one trudne do powielania przez innych lub trudno zastępowalne przez inne rodzaje zasobów w innych miejscach. Zasobów takich nie można też oddzielić od miejsca ich występowania, ponieważ są głęboko „zakorzenione” w lokalnej przestrzeni i społeczności.

Zasoby lokalne mogą więc być podstawą budowania przewagi konkurencyjnej pojedynczego podmiotu, małej jednostki terytorialnej, jak i całego regionu. Jednakże jak

\footnotetext{
1 Dla potrzeb przeprowadzonej tu analizy zmodyfikowano metodę postępowania badawczego zawartą w Diagnozie.
} 
zauważa A. Jewtuchowicz (2005), samo występowanie na danym obszarze określonego zasobu nie gwarantuje w sposób automatyczny rozwoju tego obszaru. Może on nastąpić dopiero wówczas, kiedy zasób stanie się realnym i aktywnym czynnikiem tego rozwoju. W przeciwnym razie można go uznać za zasób uśpiony lub jeszcze nieodkryty.

Najogólniej ujmując, zasoby lokalne mogą mieć charakter materialny (np. surowce naturalne, wytwarzane produkty, walory środowiskowe) i niematerialny (relacje, umiejętności i zdolności, powiązania itp.). Jest to zatem bardzo szerokie spektrum czynników, o różnorodnej genezie i poziomie oddziaływania na rozwój lokalny i regionalny. W badaniu zaproponowano podział zasobów lokalnych na sześć grup tematycznych:

1) wytwarzane produkty materialne,

2) usługi,

3) umiejętności lub wiedza,

4) lokalne zachowania i zwyczaje,

5) surowce i bogactwa naturalne,

6) wydarzenia i miejsca historyczne.

Identyfikacja zasobów lokalnych w województwie lubelskim stanowiła podstawę do budowy produktów regionalnych. Logika postępowania badawczego zakładała kilka etapów. Pierwszym z nich była identyfikacja zasobów na podstawie analizy literatury przedmiotu i innych materiałów źródłowych (dokumenty planistyczne i strategiczne, ekspertyzy, strony internetowe, sprawozdania z badań itd.). W sumie zidentyfikowano 125 zasobów. W drugim etapie polegającym na badaniach społecznych (wywiady, ankiety i warsztaty), w których uczestniczyli przedstawiciele lokalnej i regionalnej administracji oraz organizacji społecznych, przedsiębiorcy i lokalni liderzy, naukowcy, wyłoniono kolejnych 114 zasobów, różniących się od tych z etapu pierwszego.

Trzeci etap polegał na wyborze najbardziej istotnych zasobów, czyli najbardziej przydatnych w kształtowaniu nowych produktów regionalnych. Zasoby takie wyodrębnił zespół sześciu ekspertów (pracowników naukowych UMCS i IGiPZ PAN). Proces wyboru polegał na ich ocenie pod kątem dwóch kryteriów: utylitarności i unikatowości. Pod pojęciem utylitarności rozumiano wewnętrzny potencjał zasobu do osiągnięcia sukcesu rynkowego, natomiast pod pojęciem unikatowości rozumiano niepowtarzalność zasobu, która powinna stanowić podstawę jego atrakcyjności. Każdy zasób mógł otrzymać jedną z trzech ocen utylitarności (uzupełniająca - 1, istotna - 2, kluczowa - 3) oraz unikatowości (lokalna - 1, regionalna - 2, krajowa - 3). Przyjęto, że oceny ekspertów będą miały taka samą wagę; umożliwiało to ich uśrednienie. Ostatni etap polegał na ocenie powiązań pomiędzy zasobami i na konstruowaniu propozycji nowych produktów regionalnych. Przy czym ocena powiązań miała charakter jakościowy i mogła uwzględniać bardzo szeroki zakres cech oraz była uzależniona od szczegółowości materiału badawczego i wiedzy eksperta. W przypadku regionu lubelskiego zaproponowano dwadzieścia nowych produktów regionalnych, dla których bazą było 100 najwyżej ocenionych zasobów lokalnych. Poniżej przedstawiono przykłady tylko dwóch produktów regionalnych, w których tworzeniu brał udział autor tego opracowania. 


\section{Rezultaty}

Struktura wszystkich 239 zidentyfikowanych zasobów lokalnych wskazuje na przewagę w grupach: wydarzenia i miejsca historyczne oraz lokalne zachowania i zwyczaje (ryc. 1). Należy przy tym dodać, że każdy z zasobów został przypisany tylko do jednej z sześciu grup ${ }^{2}$.

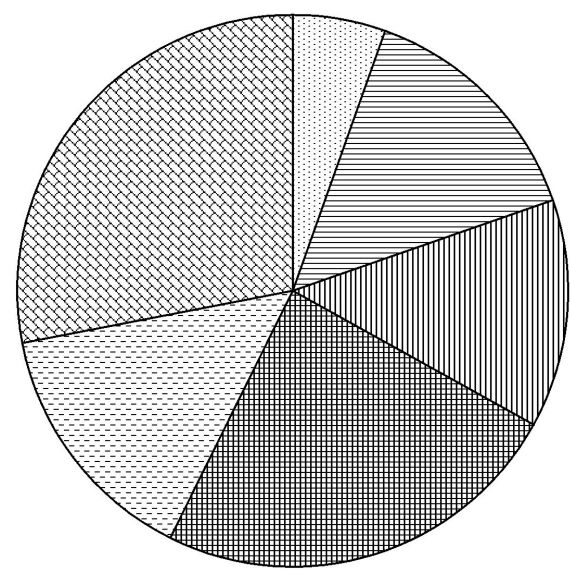

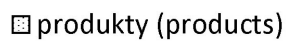

目usługi (services)

四 umiejętności lub wiedza (skills or knowledge)

田 zachowania i zwyczaje (habits and behavior)

⿴囗十) bogactwa naturalne (natural resources)

⿴囗十 wydarzenia i miejsca historyczne (events and historical sites)

Ryc. 1. Struktura zasobów wg grup tematycznych Structure of resources by thematic groups

Największą grupę stanowiły zasoby, które zostały nisko ocenione przez ekspertów, tj. posiadają niski poziom utylitarności, a ich niepowtarzalność ma na ogół charakter lokalny. Tylko siedem zidentyfikowanych zasobów uzyskało najwyższe oceny, a kolejne 13 miało oceny wysokie (tab. 1).

Tabela 1. Liczebność zasobów lokalnych wg uśrednionych ocen sześciu ekspertów

\begin{tabular}{|c|c|r|r|r|}
\hline \multirow{2}{*}{ Ocena } & \multicolumn{3}{c|}{ Unikalność } \\
\cline { 3 - 5 } \multicolumn{2}{|c|}{} & $\mathbf{1}$ & $\mathbf{2}$ & \multicolumn{1}{|c|}{$\mathbf{3}$} \\
\hline \multirow{3}{*}{ Utylitarność } & $\mathbf{1}$ & 99 & 68 & 0 \\
\cline { 2 - 4 } & $\mathbf{2}$ & 3 & 49 & 10 \\
\cline { 2 - 5 } & $\mathbf{3}$ & 0 & 3 & 7 \\
\hline
\end{tabular}

Do tego opracowania wybrano zasoby, których suma uśrednionych ocen unikalności i utylitarności wyniosła co najmniej 4. W sumie jest ich 69, a wśród nich znalazło się 15 zasobów należących do grupy surowce i bogactwa naturalne, 14 - usługi, 13 - wydarzenia i miejsca historyczne, 11 - lokalne zachowania i zwyczaje oraz po 8 - wytwarzane produkty materialne i umiejętności lub wiedza (tab. 2).

\footnotetext{
${ }^{2}$ W wersji pierwotnej zasoby mogły być włączane do więcej niż jednej grupy, co stwarzało jednak nadmierną swobodę interpretacyjną. Na przykład Roztocze było włączone równocześnie do grup: lokalnych zwyczajów i zachowań, bogactw i surowców naturalnych oraz wydarzeń i miejsc historycznych. W przypadku każdego z zasobów można wskazać wiodącą kategorię (np. dla Roztocza - bogactwa i surowce naturalne), dlatego w tym opracowaniu zdecydowano się na zasadę, że każdy zasób włączony jest tylko do jednej grupy tematycznej.
} 
Tabela 2. Zasoby lokalne, które w ocenie eksperckiej (unikalności i utylitarności) uzyskały wartość co najmniej 4 punktów (pozycje 1-7-zasoby ocenione: unikalność 3 i utylitarność 3 punkty, pozycje 8-10 odpowiednio 2 i 3 punkty, pozycje 11-20 - 3 i 2 punkty oraz pozostałe 2 i 2 punkty).

\begin{tabular}{|c|c|c|c|c|c|c|c|c|}
\hline Lp. & Zasób & $\begin{array}{l}\text { 홓 } \\
\text { 흥 } \\
\text { 임 }\end{array}$ & $\frac{8}{\frac{10}{3}}$ & 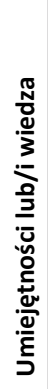 & 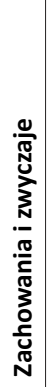 & 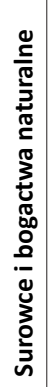 & 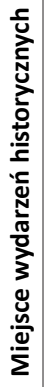 & Gmina \\
\hline 1. & Złoża gazu łupkowego & & & & & $x$ & & $\begin{array}{l}\text { Zamość, Lublin, Izbica, Krasnystaw, } \\
\text { Chełm, }\end{array}$ \\
\hline 2. & Stadnina Koni w Janowie Podlaskim & & $x$ & & & & & Janów Podlaski \\
\hline 3. & Uzdrowisko w Nałęczowie & & $x$ & & & & & Nałęczów \\
\hline 4. & Zasoby węgla kamiennego & & & & & $x$ & & $\begin{array}{l}\text { Chełm, Lubartów, Łęczna, Cyców, } \\
\text { Puchaczów }\end{array}$ \\
\hline 5. & Stare miasto w Zamościu & & & & & & $x$ & Zamość \\
\hline 6. & Kazimierz Dolny & & & & & & $x$ & Kazimierz Dolny \\
\hline 7. & Potencjał rolniczy & & & & & $x$ & & Różne gminy woj. lubelskiego \\
\hline 8. & $\begin{array}{l}\text { Złoża wapieni dla przemysłu } \\
\text { cementowego }\end{array}$ & & & & & $x$ & & Chełm, Rejowiec Fabryczny \\
\hline 9. & Zasoby wód mineralnych & & & & & $x$ & & Nałęczów, Celejów \\
\hline 10. & Placówki naukowo-badawcze & & & $x$ & & & & Lublin, Puławy \\
\hline 11. & Roztoczański Park Narodowy & & & & & $x$ & & $\begin{array}{l}\text { Zamość, Susiec, Szczebrzeszyn, } \\
\text { Zwierzyniec }\end{array}$ \\
\hline 12. & Poleski Park Narodowy & & & & & $x$ & & $\begin{array}{l}\text { Biała Podlaska, Chełm, Miedzyrzec } \\
\text { Podlaski, Terespol }\end{array}$ \\
\hline 13. & Festiwal „Dwa Brzegi” & & & & $x$ & & & Kazimierz Dolny \\
\hline 14. & Państwowe Muzeum na Majdanku & & & & & & $x$ & Lublin \\
\hline 15. & Złoża bursztynu & & & & & $x$ & & Niedźwiada \\
\hline 16. & Zasoby integrowane w obszarze Bugu & & & & $x$ & & & $\begin{array}{l}\text { Dorohusk, Wola Uhruska, Włoda- } \\
\text { wa, Terespol, Hanna, Sławatycze }\end{array}$ \\
\hline 17. & Zwiedzanie Zamościa i Lwowa & & $x$ & & & & & Zamość \\
\hline 18. & WSK łączy ludzi & & & $x$ & & & & Świdnik \\
\hline 19. & Lubelskie tytonie & $x$ & & & & & & Gminy pow. puławskiego \\
\hline 20. & $\begin{array}{l}\text { Tradycje związane z uprawą chmielu } \\
\text { i ziół }\end{array}$ & & & $x$ & & & & Gminy pow. krasnostawskiego \\
\hline 21. & Stowarzyszenie Lubelskie Drewno & & $x$ & & & & & Lublin \\
\hline 22. & $\begin{array}{l}\text { Wyciąg wakeboardowy na Zalewie } \\
\text { Zemborzyckim }\end{array}$ & & $x$ & & & & & Lublin \\
\hline 23. & $\begin{array}{l}\text { Potencjał rozwoju energii ze źródeł } \\
\text { odnawialnych }\end{array}$ & & & & & $x$ & & Różne gminy woj. lubelskiego \\
\hline
\end{tabular}


24. Piaski formierskie

25. Pałac Czartoryskich w Puławach

26. Nadwiślańska Kolejka Wąskotorowa

27. Ogród zoologiczny im. Stefana Milera

28. Monaster św. Onufrego w Jabłecznej

29. Lubelskie Podziemia

30. Filharmonia im. H. Wieniawskiego w Lublinie

31. Bitwa pod Kockiem

32. Klaster Dolina Ekologicznej Żywności

33. Zasoby gazu ziemnego

34. Uzdrowisko Krasnobród

35. Masłomęckie Stowarzyszenie Wioska Gotów

36. Zespół Fortów Twierdzy Brzeskiej

37. Europejskie Dni Dobrosąsiedztwa

38. Muzeum Wsi Lubelskiej - dwór z Żyrzyna

39. Jarmark Jagielloński w Lublinie

40. Podróż śladami opowiadań I.B. Singera

41. Cebularz lubelski

42. Uczelnia Mędrców Lublina

43. Rezerwat „Nad Tanwią”

44. Carnaval Sztuk-Mistrzów

45. Złoża fosforytów

46. Wieś tatarska - Studzianka

47. Wyższa Szkoła Oficerska Sił Powietrznych

48. Włodawa Miasto Trzech Kultur

49. Ogólnopol. Festiwal Kapel i Śpiewaków Ludowych

50. Zamek Królewski w Lublinie

51. Kraina Lessowych Wąwozów

52. Hodowla koników polskich w RPN

53. Zespół pałacowo-parkowy w Kozłówce

54. Duch Bieluch i chełmskie Podziemia Kredowe

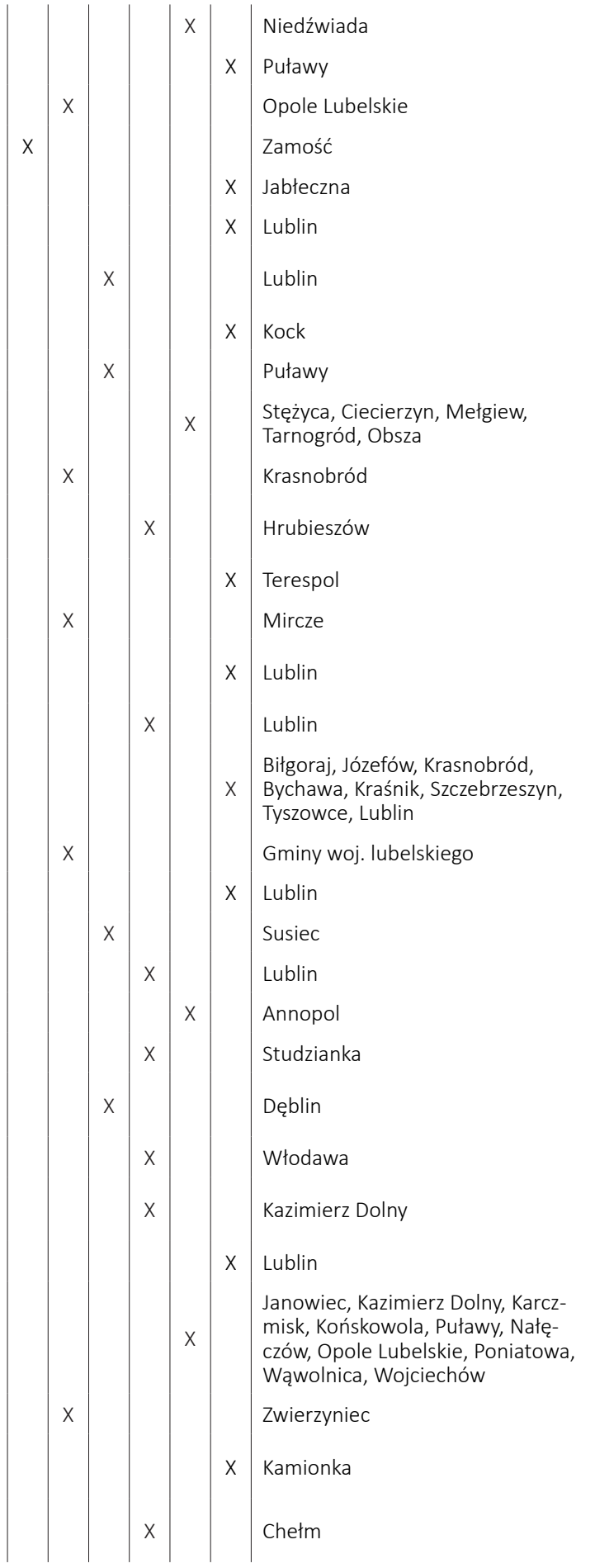




\begin{tabular}{|c|c|c|c|c|c|c|c|}
\hline 55. & Pojezierze Łęczyńsko-Włodawskie & & & & & $x$ & Włodawa, Dębowa Kłoda, Ludwin \\
\hline 56. & $\begin{array}{l}\text { Kompetencje związane z Białorusią } \\
\text { oraz Ukrainą }\end{array}$ & & & $x$ & & & $\begin{array}{l}\text { Gminy graniczące z Białorusią } \\
\text { i Ukrainą }\end{array}$ \\
\hline 57. & Trasy i ścieżki rowerowe & & $x$ & & & & Gminy pow. zamojski i biłgorajski \\
\hline 58. & Produkcja zdrowej żywności & $x$ & & & & & Gminy pow. zamojski i biłgorajski \\
\hline 59. & Możliwe klastry w okolicach Zamościa & & $x$ & & & & Zamość \\
\hline 60. & Jarmark Świętego Kiliana & & & & $x$ & & Skierbieszów \\
\hline 61. & $\begin{array}{l}\text { Międzynarodowy Festiwal Folklor. } \\
\text { „Eurofolk” }\end{array}$ & & & & $x$ & & Zamość \\
\hline 62. & Zalew w Nieliszu & & & & & $x$ & Nielisz \\
\hline 63. & Owadolandia & & $\mathrm{X}$ & & & & Wojciechów \\
\hline 64. & Śliwka Nałęczowska & $x$ & & & & & Kazimierz Dolny, Nałęczów \\
\hline 65. & Truskawkowa kraina & $x$ & & & & & Puławy \\
\hline 66. & Wina małopolskiego przełomu Wisły & $x$ & & & & & Powiat puławski \\
\hline 67. & $\begin{array}{l}\text { Zaplecze sportowe poj. } \\
\text { Łęczyńsko-Włodawskiego }\end{array}$ & & $x$ & & & & Gminy Poj. Łęczyńsko-Włodawskie \\
\hline 68. & Borówkowe zagłębie & $x$ & & & & & Wierzbica \\
\hline 60 & Lubelszczyzna - Stolica Karpia & $x$ & & & & & $\begin{array}{l}\text { Gminy pow. lubartowski, rycki, } \\
\text { parczewski }\end{array}$ \\
\hline
\end{tabular}

Źródło: opracowanie własne na podstawie Raportu Końcowego w projekcie Diagnoza zasobów lokalnych Lubelszczyzny.

Przestrzenne rozmieszczenie analizowanych zasobów wykazuje koncentrację przede wszystkim w Lublinie oraz Kazimierzu Dolnym, Zamościu, Nałęczowie i Chełmie. Niektóre z nich obejmują większe powierzchnie związane głównie z występowaniem atrakcyjnych walorów przyrodniczych (Roztoczański Park Narodowy, Poleski Park Narodowy, Dolina Bugu itp.). Zasoby, które zostały przez ekspertów najwyżej ocenione, związane są przede wszystkim z surowcami naturalnymi i walorami środowiskowymi. Mało natomiast jest zasobów wynikających z potencjału lokalnych społeczności - ich wiedzy i tradycji. Nasuwa się też wniosek, że najwyżej oceniane zasoby skupione są tylko w kilku obszarach regionu, natomiast niżej ocenione są bardziej rozproszone. Te pierwsze przynoszą już określone efekty ekonomiczne, zaś drugie pozostają jeszcze częściowo w uśpieniu i wymagają dodatkowych bodźców rozwojowych lub powiązania z aktywnymi zasobami.

Należy podkreślić, że duża część zasobów ma charakter mieszany, tj. można włączyć je do co najmniej dwóch analizowanych kategorii. Na przykład uzdrowisko w Nałęczowie włączono do kategorii usług, ale może być również uwzględnione w kategorii surowce i bogactwa naturalne. Większość badanych zasobów ma unikalność na poziomie regionalnym, a utylitarność na poziomie istotnym. Jednakże w przypadku siedemnastu zasobów uznano, że ich unikalność ma wymiar krajowy, a tylko dziesięć zasobów ma utylitarność kluczową. Trudno zatem oczekiwać, aby wszystkie wysoko oceniane zasoby kształtowały przewagę konkurencyjną regionu i stymulowały rozwój gospodarczy. Pewnym rozwiązaniem może być tworzenie produktów regionalnych wykorzystujących potencjał zespołu zasobów i dzięki temu zwiększy się poziom ich praktycznego wykorzystania. 


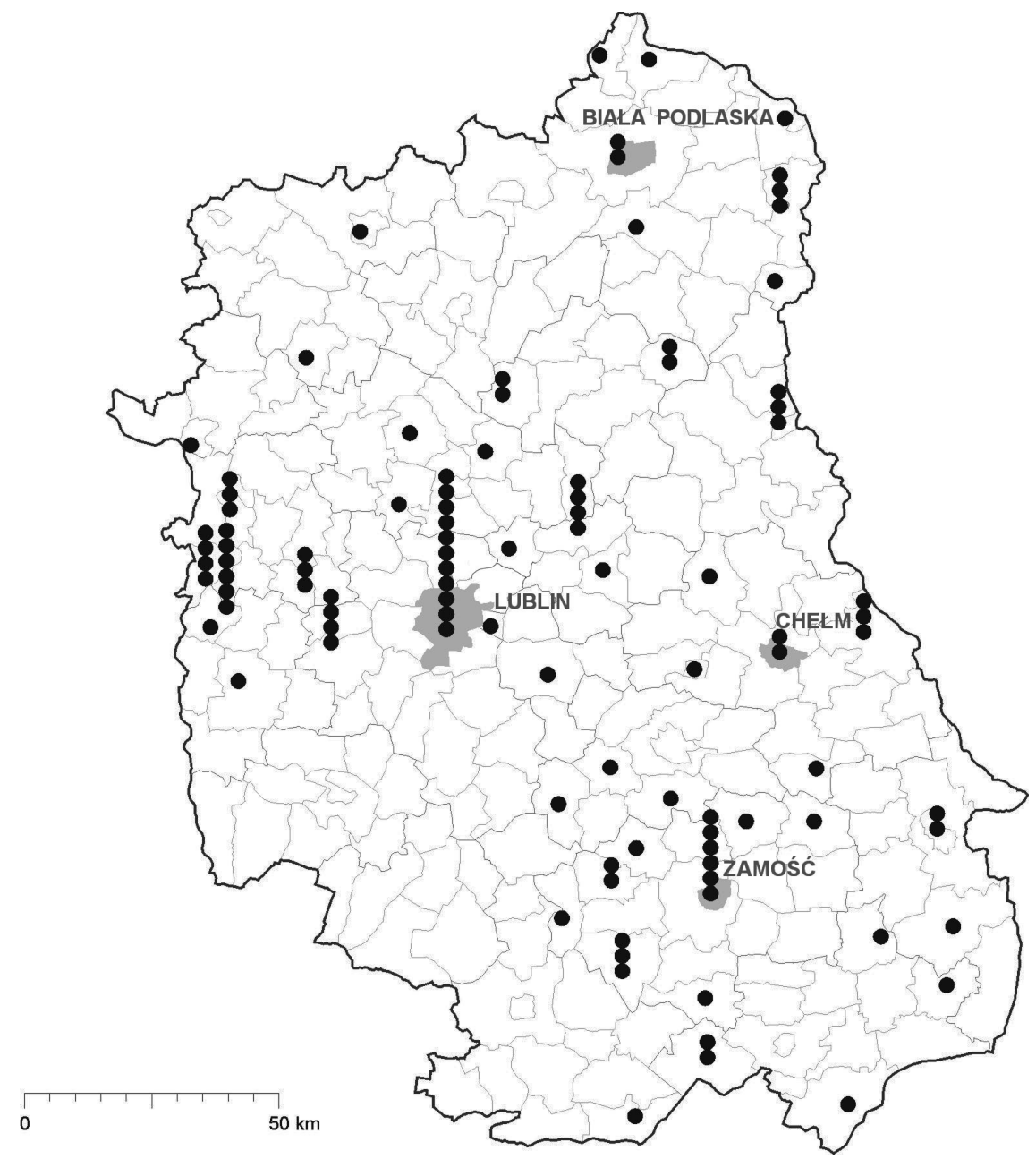

Ryc. 2. Rozmieszczenie 100 najważniejszych zasobów lokalnych na terenie województwa lubelskiego Źródło: opracowanie własne na podstawie: Raport końcowy... (2015).

Localization of the 100 most important local resources in the Lublin region Source: own research based on the Raport końcowy... (2015).

Analiza powiązań pomiędzy zasobami pozwala łączyć je w grupy, które stanowią podstawę do opracowania propozycji nowych produktów regionalnych. Produkty takie mogą tworzyć nowe przewagi konkurencyjne regionu i jednocześnie zwiększać efektywność wykorzystania jednostkowych zasobów lokalnych. Jednym z najwyżej ocenianych zasobów jest uzdrowisko w Nałęczowie, któremu towarzyszy drugi ważny zasób - wody mineralne, a dodatkowo w okolicy uzdrowiska zidentyfikowano kilka innych kategorii zasobów, które można powiązać z zasobem głównym. Wszystkie one umożliwiają sformułowanie propozycji nowego produktu regionalnego - Srebrna gospodarka w Nałęczowie, którego celem jest stworzenie oprócz usług czysto sanatoryjnych, nowoczesnych centrów SPA i chirurgii plastycznej o skali krajowej lub europejskiej. Dzięki temu przedsiębiorstwa usługowe w Nałęczowie będą mogły rozszerzyć zasięg swojego działania na pobliskie gminy, zwłasz- 
cza Celejów. Proponuje się także nawiązanie bliższej współpracy z analogicznymi podmiotami działającymi na Roztoczu, głównie w Krasnobrodzie.

Produkt Srebrna gospodarka ma na celu stworzenie unikatowej, szerokiej oferty usług zdrowotnych skierowanych głównie do osób dojrzałych wiekowo i osób starszych z kraju i zagranicy. W produkcie powinny być wykorzystane różne kategorie zasobów, w tym uwzględniające instytucje i ich kompetencje (instytucje medyczne, lekarze i personel pomocniczy) oraz lokalne walory środowiskowe (wody mineralne, tereny rekreacyjne i turystyczne). W rezultacie wykorzystać będzie można duże spektrum innych zasobów lokalnych, w tym: Krainę Lessowych Wąwozów i zasoby związane z Kazimierzem Dolnym zwiększające atrakcyjność i urozmaicające pobyt osób korzystających z usług w Nałęczowie, potencjał naukowo-badawczy Lublina we wdrażaniu nowych technik medycznych i kształceniu wyspecjalizowanej kadry lekarskiej, potencjał rolniczy w produkcji czystej żywności (głównie owoców i warzyw) promowanej wśród kuracjuszy. Srebrnej gospodarce powinno też towarzyszyć lecznictwo naturalne, produkcja kosmetyków i materiałów pielęgnacyjnych oraz rozbudowa ścieżek spacerowych (np. przystosowanych do nordic walking).

Aby wdrożyć produkt, niezbędna jest jego promocja oraz tworzenie sieci powiązań pomiędzy wymienionymi wcześniej zasobami lokalnymi. Należy zachęcać firmy oferujące usługi związane ze srebrną ekonomią do lokalizacji swojej działalności w miejscowościach położonych w sąsiedztwie Nałęczowa. Dodatkowo potrzebna jest promocja samego Nałęczowa, jako ośrodka idealnego do spędzenia wolnego czasu i odpoczynku, przede wszystkim dla osób starszych i chcących poprawić swoje zdrowie, urodę i kondycję fizyczną. Kampania promocyjna powinna być prowadzona w ośrodkach opieki zdrowotnej i klubach zrzeszających osoby starsze. Warto ją prowadzić w Polsce, a także w innych krajach, głównie w Niemczech i krajach skandynawskich. Aby stworzyć w okolicach Nałęczowa miejsce dla rozwoju srebrnej ekonomii potrzebny jest także rozwój bazy hotelarskiej i gastronomicznej.

Drugi przykład produktu regionalnego - Lubelski akademicki inkubator przedsiębiorczości - wynika z zasobów akademickich Lublina i Puław. Jego podstawowym celem jest pobudzenie innowacyjności młodych ludzi, przede wszystkim studentów, a także pracowników naukowych oraz absolwentów kończących studia. Produkt może być kształtowany na bazie już istniejących: Podstrefy Lublin Specjalnej Strefy Ekonomicznej EURO-PARK, Portu Lotniczego Lublin oraz Inkubatora Technologicznego w Lublinie. Elementem takiego produktu byłby start-up centre wykorzystujący infrastrukturę uczelni lubelskich, wspierający nowo tworzone firmy, zapewniający powierzchnie biurowe, sale konferencyjne oraz dostęp do usług księgowych, informatycznych itp. Centrum takie ułatwi wprowadzenie nowych pomysłów biznesowych i rozpoczęcie działalności nowym firmom.

Efektem wdrożenia produktu jest rozwój przedsiębiorczości w regionie oraz zwiększenie zatrudnienia wśród absolwentów uczelni wyższych. Sukces produktu zwiększy jeszcze liczbę studentów w Lublinie, zahamuje odpływ z regionu najzdolniejszych jednostek, a także pozwoli kojarzyć miasto z nowoczesnym i międzynarodowym ośrodkiem naukowym. Ponadto potencjał naukowo-badawczy zwiększy efektywność wykorzystanie innych zasobów lokalnych; na przykład na bazie IUNG w Puławach i Uniwersytetu Rolniczego w Lublinie można zwiększać efektywność produkcji rolnej i przetwórstwa spożywczego w zakresie produkcji zdrowej żywności, przetwórstwa owocowego, produkcji chmielu itp. 


\section{Wnioski}

Zasoby lokalne to elementy potencjału wewnętrznego określonego terytorium stwarzające możliwości generowania nowych impulsów rozwojowych poprzez kształtowane w tym celu produkty. Wśród zasobów lokalnych można wyróżnić zasoby aktywne - czyli uczestniczące w rozwoju terytorialnym i będące już w obrocie gospodarczym oraz zasoby uśpione wymagające bodźców pobudzających. Należy przyjąć, że zasoby „aktywne” mogą wchodzić w interakcje z zasobami „uśpionymi”, dając podstawę dla tworzenia nowych produktów.

Lubelszczyzna ma zróżnicowaną strukturę zasobów lokalnych, w której najwięcej jest usług i zasobów związanych z umiejętnościami oraz elementami kulturowymi. Zasięg przestrzenny ich oddziaływania jest jednak zazwyczaj bardzo ograniczony. Poziom unikatowości i utylitarności zasobów regionu jest w ocenie ekspertów średni lub niski; przeciętny poziom unikatowości 100 wybranych przez nich zasobów w skali trzystopniowej został oceniony na poziomie 2,0, zaś przeciętny poziom utylitarności na poziomie 1,6. Wśród zasobów, które uzyskały najwyższą ocenę (unikatowość krajowa oraz utylitarność kluczowa), znalazły się: Stare Miasto w Zamościu, Kazimierz Dolny, zasoby węgla kamiennego w LZW, uzdrowisko w Nałęczowie, stadnina koni w Janowie Podlaskim, zasoby gazu łukowego, potencjał rolniczy.

Zidentyfikowane zasoby regionu mają silne związki z turystyką i rekreacją, tzn. stwarzają przede wszystkim możliwości kształtowania nowych produktów związanych z usługami turystycznymi. Należy do nich większość zasobów związanych ze specyficznymi umiejętnościami, usługą utożsamianą ze społecznością lub miejscem, zachowaniem lub zwyczajami społeczności lokalnych oraz miejscem wydarzeń historycznych. Mając na uwadze peryferyjne położenie regionu, ograniczoną jego dostępność dla wypoczynku sobotnio-niedzielnego oraz stosunkowo nieduży wewnętrzny potencjał usługobiorców należy stwierdzić, że nowe produkty turystyczne mogą być mało efektywne. Dlatego należy je koncentrować wokół najważniejszych zasobów gwarantujących sukces produktu. Produkty turystyczne powinny też trafiać do określonych grup odbiorców i mieć wyspecjalizowany charakter.

Znaczną część zasobów skupionych przestrzennie cechuje wysoki poziom utylitarności. Natomiast większość zasobów z pojedynczych lokalizacji wykazuje najniższy, uzupełniający poziom utylitarności. Wynika to z faktu, że skupienia zasobów występują w dużych ośrodkach miejskich, gdzie bezpośrednie sąsiedztwo innych zasobów generuje wartość dodaną i wystąpienie efektu skali. Natomiast zasoby z pojedynczych lokalizacji pozostają często w uśpieniu i impulsem do ich rozwoju byłoby związanie z zasobami aktywnymi o wysokim poziomie utylitarności.

Za symptomatyczne należy uznać, że znaczna liczba zidentyfikowanych zasobów i wskazanych na ich podstawie produktów bazuje na kapitale społecznym, pomysłowości i oddolnych inicjatywnych mieszkańców - są to różnego rodzaju wydarzenia kulturalne, działalność przetwórczo-usługowa czy niestandardowa oferta turystyczna. Daje to solidną podstawę do dalszego rozwoju zainicjowanych działań.

Artykuł został sfinansowany ze środków Narodowego Centrum Nauki przyznanych projektowi badawczemu nr 2015/19/B/HS4/01298 


\section{Literatura}

Blakely E.J., 1989, Planning local economic development. Theory and practice, Sage, London-New York.

Brandenburg H., 2011, Zarzqdzanie lokalnymi projektami rozwojowymi, Uniwersytet Ekonomiczny, Katowice.

Brol R., 1998, Zarzqqdzanie rozwojem lokalnym - studium przypadki, Akademia Ekonomiczna, Wrocław.

Camagni R., 2008, Regional Competitiveness: Towards a Concept of Territorial Capital, [w:] R. Capello, R. Camagni, B. Chizzolini, U. Fratesi (red.), Modelling Regional Scenarios for the Enlarged Europe, Springer, Berlin-Heidelberg, s. 33-47.

Dutkiewicz P., Gorzelak G. (red.), 1988, Problemy rozwoju lokalnego, Rozwój regionalny, rozwój lokalny, samorząd terytorialny, 11, UW, Warszawa.

Friedman T., 2001, Lexus i drzewo oliwne. Zrozumieć globalizację, Dom Wydawniczy Rebis, Poznań.

Fujita M., Krugman P., Venables A., 1999, The Spatial Economy: Cities, Regions, and International Trade, MIT Press, Cambridge, MA.

Gorzelak G., 2008, Polska lokalna 2007 - synteza, [w:] G. Gorzelak (red.), Polska lokalna 2007, Wydawnictwo Naukowe Scholar, Warszawa, s. 10-31.

Heffner K., 2007, Rozwój społeczno-gospodarczy obszarów wiejskich. Definicje - uwarunkowania - zależności - czynniki - skutki. Badania zróżnicowania rozwoju obszarów wiejskich, [w:]

A. Rosner (red.), Zróżnicowanie poziomu rozwoju społeczno-gospodarczego obszarów wiejskich a zróżnicowanie dynamiki przemian, IRWiR PAN, Warszawa, s. 11-26.

Hryniewicz J. (red.), 1990, Społeczności lokalne u progu przemian ustrojowych, Rozwój regionalny, rozwój lokalny, samorząd terytorialny, 24, UW, Warszawa.

Jałowiecki B., 1989, Rozwój lokalny, Rozwój regionalny, rozwój lokalny, samorząd terytorialny, 16, UW, Warszawa.

Jewtuchowicz A., 2013, Terytorium i współczesne dylematy jego rozwoju, Wydawnictwo Uniwersytetu Łódzkiego.

Knieć W., 2010, Partnerstwa lokalne w Polsce - kondycja, struktura, wyzwania. Raport badawczy, Fundacja Partnerstwo dla Środowiska, Kraków-Toruń.

Komunikat Komisji EUROPA 2020 Strategia na rzecz inteligentnego i zrównoważonego rozwoju sprzyjajqcego włączeniu społecznemu, 2010, Bruksela.

Parysek J., 1996 (red.), Rozwój lokalny i lokalna gospodarka przestrzenna, Bogucki Wydawnictwo Naukowe, Poznań.

Parysek J., 1997, Podstawy gospodarki lokalnej, Wydawnictwo Naukowe UAM, Poznań.

Pretty J., 1999, O zrównoważonym rozwoju gospodarki lokalnej, Fundacja Wspomagania Wsi, Warszawa (tłumaczenie broszury Sustainable Development for Local Economies).

Raport końcowy, Usługa przeprowadzenia badania i opracowania raportu na temat: Diagnoza zasobów lokalnych Lubelszczyzny realizowanego w ramach projektu „Regionalne Obserwatorium Terytorialne w województwie lubelskim” wspótfinansowanego ze środków Unii Europejskiej w ramach Europejskiego Funduszu Społecznego, Program Operacyjny Kapitał Ludzki, Priorytet V Dobre rzqdzenie, Działanie 5.2 Wzmocnienie potencjału administracji samorzqdowej, Poddziatanie 5.2.1 Modernizacja zarządzania w administracji samorzqdowej, 2015, Agrotec, Warszawa.

Romer P.M., 1990, Endogenous Technological Change, Quarterly Journal of Economics, 98, s. 71-102.

Scott A.J., Storper M., 2003, Regions, globalization, development, Regional Studies, 37, s. 579-593. 
Sekuła A., 2001, Koncepcje rozwoju lokalnego w świetle współczesnej literatury polskiej - zarys problemu, Zeszyty Naukowe Politechniki Gdańskiej, 588, Ekonomia 40, Politechnika Gdańska, Gdańsk, s. 89-95.

Sobala-Gwosdz A., 2005, Ośrodki wzrostu i obszary stagnacji w województwie podkarpackim, Uniwersytet Jagielloński, Kraków.

Starosta P. (red.), 2012, Zróżnicowanie zasobów kapitału ludzkiego i społecznego w regionie łódzkim, Wydawnictwo Uniwersytetu Łódzkiego, Łódź.

Trojanek M., 1994, Oddziaływanie władzy lokalnej na efektywność przedsięwzięć innowacyjnych, Zeszyty Naukowe Akademii Ekonomicznej w Poznaniu, 2, 137, Poznań.

Wasielewski K. (red.), 2009, Tworzenie partnerstw lokalnych i ich sieci na obszarach wiejskich. Doświadczenia z funkcjonowania programu Leader w Polsce w latach 2004-2009, Wydawnictwo Uczelniane Wyższej Szkoły Gospodarki, Bydgoszcz.

\section{Summary}

The local resources give rise to the competitive advantages of the area, on which they appear, since they are characterised by the rarity of occurrence. They can hardly be duplicated by the others or can hardly be replaced by other kinds of resources in other places. Further, such resources cannot be separated from the place of their appearance; they are deeply "rooted" in the local space and local society. Local resources may, therefore, constitute the basis for the development of the competitive edge of a single business, a small territorial unit, as well as an entire region.

Local resources, in most general terms, may have material character (raw materials, products, environmental qualities, etc.) or the non-material one (interrelations, skills and capacities, interconnections, culture, etc.). Thus, we deal with a very wide spectrum of factors, having diverse origins and influencing the local and regional development in a variety of ways. These factors display also high spatial differentiation, owing to which they provide the possibility of elaborating various development scenarios and strategic solutions in the regions. A set of resources can be the basis to develop new products that will increase the region's competitiveness.

The main objective of this paper is the spatial identification and diagnosis of the specific resources in the Lublin region, as well as the assessment of their development-related potential. Examined region has a diversified structure of local resources, where predominate services and cultural elements. The spatial extent of their influence, however, is usually very limited. The level of uniqueness and usability of resources is usually medium or low and they have strong links with tourism and recreation. Among the resources that received the highest rating are: the Old Town in Zamość, Kazimierz Dolny town, coal, spa in Nałęczów town, stud in Janów Podlaski and high agricultural potential. 
http://rcin.org.pl 